\title{
Expanding the Scope of Alcohol Dehydrogenases towards Bulkier Substrates: Stereo- and Enantiopreference for $\alpha, \alpha-$ Dihalogenated Ketones
}

\author{
Kinga Kędziora, ${ }^{[\mathrm{a}]}$ Fabricio R. Bisogno, ${ }^{[\mathrm{a}, \mathrm{b}]}$ Iván Lavandera, ${ }^{[\mathrm{a}]}$ Vicente Gotor- \\ Fernández, ${ }^{[\mathrm{a}]}$ Jose Montejo-Bernardo, ${ }^{[\mathrm{c}]}$ Santiago García-Granda, ${ }^{[\mathrm{c}]}$ Wolfgang \\ Kroutil, ${ }^{[\mathrm{d}]}$ and Vicente Gotor ${ }^{*[a]}$
}

Alcohol dehydrogenases (ADHs) were identified as suitable enzymes for the reduction of the corresponding $\alpha, \alpha$-dihalogenated ketones, obtaining optically pure $\beta, \beta$-dichloro- or $\beta, \beta$-dibromohydrins with excellent conversions and enantiomeric excess. Among the different biocatalysts tested, ADHs from Rhodococcus ruber (ADH-A), Ralstonia sp. (RasADH), Lactobacillus brevis (LBADH), and PR2ADH proved to be the most efficient ones in terms of activity and stereoselectivity. In a further study, two racemic a-substituted

\section{Introduction}

$\beta, \beta$-Dihalogenated alcohols, also called gem-dihalo alcohols or $\beta, \beta$-dihalohydrins, ${ }^{[1]}$ are a family of interesting compounds due to their versatility in organic synthesis, ${ }^{[2]}$ and because of their role as precursors of biologically active derivatives such as antineoplastic drugs like mitotane. ${ }^{[3]}$ Thus, as a result of the highly activated nature of these compounds, they can be used as synthetic intermediates of interesting molecules such as alkenes, ${ }^{[4]}$ terminal alkynes, ${ }^{[5]}$ epoxides, ${ }^{[6]}$ and a-methoxy alkyl acetic acid derivatives. ${ }^{[7]}$ Also due to their reactivity in aqueous medium, they have been described as chemical analogues of a-hydroxy aldehydes, opening the scope towards other types of substrates, e.g. $\alpha$-hydroxy acids (Scheme 1). ${ }^{[8]}$

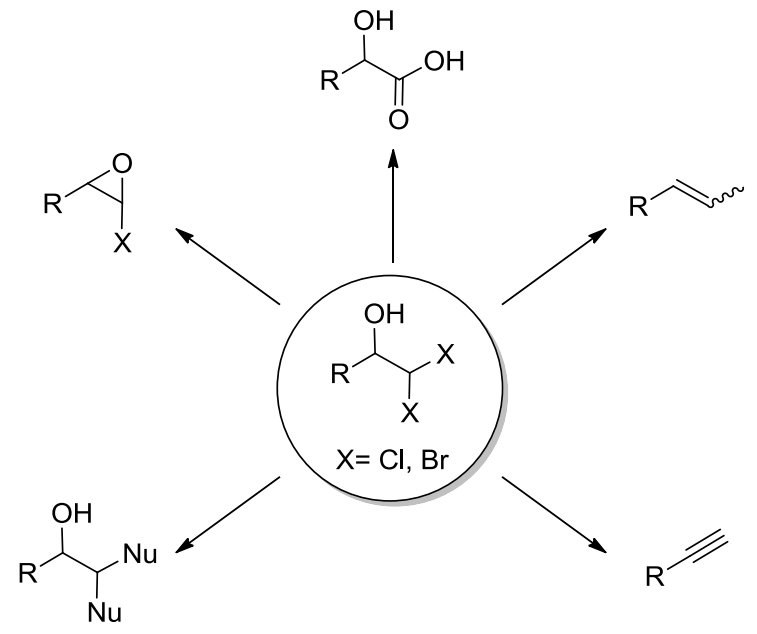

Scheme 1. Synthetic applicability of the gem-dihalo alcohol core. ketones, namely $\alpha$-bromo- $\alpha$-chloro- and $\alpha$-chloro- $\alpha$ fluoroacetophenone were investigated in order to obtain one of the four possible diastereoisomers through a dynamic kinetic process. In the case of the brominated derivative, only the $(1 R)$-enantiomer was obtained using $\mathrm{ADH}-\mathrm{A}$ although with moderate diastereomeric excess ( $>99 \%$ ee, $63 \%$ de), while the fluorinated ketone showed a lower stereodiscrimination (up to $45 \%$ de).

The preparation of the racemic derivatives can be achieved by means of different synthetic approaches such the Hunsdiecker reaction, ${ }^{[9]}$ the decarboxylative heterodifunctionalisation of $\alpha, \beta$ unsaturated carboxylic acids, ${ }^{[10]}$ or the reduction of the corresponding ketone precursors. ${ }^{[11]}$ Unfortunately, these methods usually afford a mixture of products due to the formation, among others, of dehydrated, hydrolysed or over-reduced compounds. Even more difficult is to find in the literature an appropriate methodology to stereoselectively achieve these chiral precursors. Unfortunately, the selectivity obtained in these processes by reduction of the ketones using chiral oxaborolidine $^{[12]}$ or borane complexes were moderate $(<83 \%),{ }^{[13]}$ and alternatively, dichlorocarbene $\mathrm{C}-\mathrm{H}$ insertion reactions ${ }^{[14]}$ led to incomplete conversions $(<90 \%)$ starting from an expensive enantiopure alcohol precursor.

Interestingly, the use of biocatalytic methods under mild reaction

[a] K. Kędziora, Dr. F. R. Bisogno, Dr. I. Lavandera, Dr. V. GotorFernández, Prof. V. Gotor

Department of Organic and Inorganic Chemistry

University of Oviedo

Avenida Julián Clavería s/n, 33006 Oviedo, Spain

E-mail:vgs@uniovi.es

[b] Dr. F. R. Bisogno

INFIQC-CONICET, Dpto. de Química Orgánica, Facultad de Ciencias Químicas

Universidad Nacional de Córdoba

Ciudad Universitaria, CP 5000, Córdoba, Argentina

[c] Dr. J. Montejo-Bernardo, Prof. S. García-Granda

Departamento de Química Física y Analítica

Universidad de Oviedo

Avenida Julián Clavería s/n. Oviedo 33006 (Asturias)

[d] Prof. W. Kroutil

Department of Chemistry, Organic and Bioorganic Chemistry

University of Graz

Heinrichstrasse 28, 8010 Graz, Austria

Supporting information for this article is available on the WWW under http://dx.doi.org/10.1002/cctc.200xxxxxx. 
conditions has allowed the selective synthesis of difluorohydrins, ${ }^{[15]}$ However, for the chlorinated or brominated counterparts, and although the formation of by-products was minimised, the enantioselectivities or yields obtained in these processes were still not high enough. For instance, $(R)-2,2-$ dibromo-1-(4'-benzyloxy-3'-hydroxymethylphenyl)ethanol was obtained in $82 \%$ yield and $92 \%$ ee using Rhodotorula rubra whole cells in the presence of a surfactant. ${ }^{[16]}$ The lipase-catalysed resolution of 2,2-dichloro-1-phenylethanol (3a) was achieved with Amano Pseudomonas cepacia lipase (PSL), but $44 \%$ conversion of the final product was reached after $142 \mathrm{~h} .{ }^{[17]}$ On the other hand, the bioreduction of the $\alpha, \alpha$-dihalo ketone precursor $2 a$ has been tested with whole cells from Geotrichum candidum APG ${ }^{[18]}$ and baker's yeast, ${ }^{[19]}$ but stereoselectivities remained modest $(<55 \%$ $e e)$. Based on the high selectivities displayed by alcohol dehydrogenases $(\mathrm{ADHs}),{ }^{[20]}$ and since $\alpha$-monohalogenated ketones are excellent substrates for these enzymes, ${ }^{[21]}$ the bioreduction of a series of bulkier $\alpha, \alpha$-dihalogenated acetophenones is here presented. With that purpose, several partially purified/overexpressed $A D H s$ have been tested to gain access to the enantiopure $\beta, \beta$-dihalohydrins. Moreover, the reduction of two racemic derivatives was also tried in order to study the formation of two contiguous stereocentres in a dynamic kinetic resolution (DKR) process catalysed by an $\mathrm{ADH}$ through racemisation in basic conditions.

\section{Results and Discussion}

\section{Preparation of $\alpha, \alpha$-dihaloacetophenones and the corresponding alcohols}

The synthesis of $\mathbf{a}, \boldsymbol{\alpha}$-dichloroacetophenones $\mathbf{2} \mathbf{a}-\mathbf{h}$ was performed in good to very high yields starting from commercially available acetophenones $\mathbf{1} \mathbf{a}-\mathbf{h}$, bearing different substitution pattern in the aromatic ring, by reaction with a 2 -fold molar excess of $N$ chlorosuccinimide (NCS) in the presence of $p$-toluenesulfonic acid $(p-\mathrm{TsOH})$ using acetonitrile as solvent at $50 \stackrel{\circ}{\mathrm{C}}$ (Table 1$)$.

\begin{tabular}{|c|c|c|c|}
\hline \multicolumn{2}{|c|}{$\underbrace{\mathrm{x}}_{1 \mathrm{a}-\mathrm{h}}$} & $\begin{array}{l}\mathrm{S} \\
\mathrm{Mec} \\
6-48\end{array}$ & 2a-h \\
\hline Entry & $x$ & $\mathrm{t}[\mathrm{h}]$ & 2a-h $[\%]^{[a]}$ \\
\hline 1 & $\mathrm{H}$ & 16 & 77 (a) \\
\hline 2 & 2-Me & 48 & $82(\mathbf{b})$ \\
\hline 3 & $2-\mathrm{Cl}$ & 48 & 77 (c) \\
\hline 4 & 3-OMe & 16 & 75 (d) \\
\hline 5 & $3-\mathrm{NO}_{2}$ & 16 & $80(\mathbf{e})$ \\
\hline 6 & $3-\mathrm{Cl}$ & 16 & 78 (f) \\
\hline 7 & $4-\mathrm{NO}_{2}$ & 16 & $78(\mathbf{g})$ \\
\hline 8 & 4-Cl & 16 & $90(\mathrm{~h})$ \\
\hline
\end{tabular}

[a] Isolated yields of prochiral ketones 2a-h after flash chromatography. In brackets appears the identification of the corresponding $\alpha, \alpha$,-dihalogenated acetophenone, 2a-h obtained from 1a-h. For more details see the Experimental Section.
A lower reactivity for the ortho-substituted derivatives $\mathbf{2 b}$-c was observed, so longer reaction times were required in these cases (entries 2 and 3), probably due to sterical hindrance. In addition, to achieve the synthesis of 2,2-dichloro-1-(3,4dichlorophenyl)ethanone (2i), the corresponding $\alpha$ chloroacetophenone derivative 1i was used as starting material utilising 1.1 equiv. of NCS, obtaining $2 \mathbf{i}$ in $83 \%$ yield. Starting from 1a with a 3-fold molar excess of $N$-bromosuccinimide (NBS), 2,2dibromoacetophenone 2j was achieved in $81 \%$ isolated yield. Racemic dihalohydrins $\mathbf{3 a}$-j were obtained in good to very high yields $(70-96 \%)$ by reduction of the corresponding ketones with $\mathrm{NaBH}_{4}$ in $\mathrm{MeOH}$ at room temperature (see Supporting Information).

\section{Bioreduction of prochiral $\alpha, \alpha$-dihaloketones 2a-j}

Once synthesised, the asymmetric bioreduction of $\alpha, \alpha-$ dihaloketones 2a-j was studied using commercially available and overexpressed ADHs. Due to our previous experience with similar a-halogenated substrates, ${ }^{[15 a, 21 c, 21 f]}$ six enzymes were used in this study, including also those accepting bulky-bulky ketones as substrates: ADH-A from Rhodococcus ruber, ${ }^{[22]}$ RasADH from Ralstonia sp. ${ }^{[23]}$ and SyADH from Sphingobium yanoikuyae, ${ }^{[24]}$ which are Prelog enzymes; ${ }^{[25]}$ and on the other hand LBADH from Lactobacillus brevis, ${ }^{[26]} \mathrm{LKADH}$ from Lactobacillus kefir, ${ }^{[27]}$ and PR2ADH that are anti-Prelog ADHs (see the Experimental Section for more details). All these biocatalysts accept aromatic ketones bearing a small substituent at alpha position such as methyl or chloromethyl. Besides, RasADH and SyADH can also reduce bulkier substrates. ${ }^{[23,24]}$ Except for RasADH and LKADH, where glucose and glucose dehydrogenase (GDH) were used to recycle a catalytic amount of the nicotinamide cofactor, 2propanol was employed as hydrogen donor $(5 \% \mathrm{v} / \mathrm{v})$. This is due to the fact that RasADH and LKADH work better under these conditions as previously described. ${ }^{[23 c, 28]}$ For clarity, the best results for the synthesis of both $\mathbf{3 a} \mathbf{a}$-j enantiomers are collected in Table 2, while in the Supporting Information more detailed information about the screening process can be found.

Satisfyingly, from the twenty possible enantiopure alcohols, fifteen were obtained in enantiomerically pure form, finding $A D H$ $A, L B A D H$ and PR2ADH as the most versatile biocatalysts for the stereoselective reduction of $\alpha, \alpha$-dihaloacetophenones, being achieved in eighteen cases with at least $90 \%$ conversion. Initially a, $\alpha$-dichloroacetophenone (2a) was studied yielding selectively either enantiomer of alcohol $3 \mathbf{a}$ in conversions over $95 \%$ by using a Prelog enzyme $(\mathrm{ADH}-\mathrm{A}$, entry 1$)$ or anti-Prelog reductases (PR2ADH and LBADH, entries 2 and 3). Then, the influence of electron donating ( $\mathrm{Me}$ or $\mathrm{OMe}$ ) or electron withdrawing substituents $\left(\mathrm{Cl}\right.$ or $\left.\mathrm{NO}_{2}\right)$, at different positions in the aromatic ring was studied for $\mathbf{\alpha}$, $\mathbf{\alpha}$-dichloroacetophenone derivatives $\mathbf{2 b}$-i. Clear trends were observed as follows: (i) ADHs led to good levels of activity and stereoselectivity to those substrates with the presence of substituents in the meta- or para-position (entries 820), while for ortho-substituted acetophenones $\mathbf{2 b , c}$ (entries 4-7), only the Prelog enzyme RasADH (entries 4 and 6) allowed the isolation of the corresponding $(R)$-alcohols in quantitative yield and enantiopure form. This is especially relevant since the bioreduction of ortho-substituted acetophenones remains usually hampered. In a recent contribution RasADH showed good activity for similar ketones; ${ }^{[23 b]}$ (ii) 'bulky-bulky' ADH from Ralstonia sp. was identified as the best enzyme for highly hindered substrates; ${ }^{[23]}$ (iii) $\mathrm{ADH}-\mathrm{A}$ demonstrated also high versatility acting 
as a very selective enzyme, ${ }^{[22]}$ only leading to low conversion in the case of the 2-methyl derivative $\mathbf{2 b}$ (see also Supporting Information). Thus, a correct choice between RasADH or ADH-A allowed the synthesis of the $(R)$-alcohols with excellent stereoselectivities and conversions; (iv) the poorest results were generally attained with LKADH, which seemed to be not suitable for dihalohydrins synthesis.

\begin{tabular}{|c|c|c|c|c|c|c|}
\hline \multicolumn{2}{|c|}{ 2a-j } & \multicolumn{3}{|c|}{$\begin{array}{c}\text { ADH } \\
\text { NAD(P)H } \\
\mathrm{s} \mathrm{Buffer} \mathrm{pH} 7.5 \\
24 \mathrm{~h}, 30^{\circ} \mathrm{C} \\
150 \mathrm{rpm}\end{array}$} & \multicolumn{2}{|c|}{$3 a-j$} \\
\hline Entry & $x$ & $Y$ & $z$ & $\mathrm{ADH}$ & $\mathrm{c}[\%]^{[\mathrm{a}]}$ & $e e[\%]^{[b]}$ \\
\hline 1 (a) & $\mathrm{H}$ & $\mathrm{Cl}$ & $\mathrm{Cl}$ & A & 96 & $>99(R)$ \\
\hline 2 (a) & $\mathrm{H}$ & $\mathrm{Cl}$ & $\mathrm{Cl}$ & PR2 & 99 & $>99(S)$ \\
\hline $3(\mathbf{a})$ & $\mathrm{H}$ & $\mathrm{Cl}$ & $\mathrm{Cl}$ & LB & 99 & $>99(S)$ \\
\hline $4(\mathbf{b})$ & 2-Me & $\mathrm{Cl}$ & $\mathrm{Cl}$ & E. coli/Ras & 99 & $>99(R)$ \\
\hline $5(\mathbf{b})$ & 2-Me & $\mathrm{Cl}$ & $\mathrm{Cl}$ & PR2 & 43 & $>99(S)$ \\
\hline $6(\mathrm{c})$ & $2-\mathrm{Cl}$ & $\mathrm{Cl}$ & $\mathrm{Cl}$ & E. coli/Ras & 99 & $>99(R)$ \\
\hline 7 (c) & $2-\mathrm{Cl}$ & $\mathrm{Cl}$ & $\mathrm{Cl}$ & LB & 12 & $91(S)$ \\
\hline $8(d)$ & 3-OMe & $\mathrm{Cl}$ & $\mathrm{Cl}$ & E. coli/A & 99 & $>99(R)$ \\
\hline $9(d)$ & 3-OMe & $\mathrm{Cl}$ & $\mathrm{Cl}$ & PR2 & 99 & $>99(S)$ \\
\hline $10(\mathbf{d})$ & 3-OMe & $\mathrm{Cl}$ & $\mathrm{Cl}$ & LB & 99 & $>99(S)$ \\
\hline $11(\mathbf{e})$ & 3- $\mathrm{NO}_{2}$ & $\mathrm{Cl}$ & $\mathrm{Cl}$ & A & 99 & $>99(R)$ \\
\hline $12(\mathbf{e})$ & 3- $\mathrm{NO}_{2}$ & $\mathrm{Cl}$ & $\mathrm{Cl}$ & LB & 96 & $>99(S)$ \\
\hline $13(f)$ & $3-\mathrm{Cl}$ & $\mathrm{Cl}$ & $\mathrm{Cl}$ & A & 99 & $96(R)$ \\
\hline $14(\mathbf{f})$ & $3-\mathrm{Cl}$ & $\mathrm{Cl}$ & $\mathrm{Cl}$ & $\mathrm{LB}^{[\mathrm{c}]}$ & 99 & $>99(S)$ \\
\hline $15(\mathbf{g})$ & $4-\mathrm{NO}_{2}$ & $\mathrm{Cl}$ & $\mathrm{Cl}$ & A & 97 & $>99(R)$ \\
\hline $16(\mathbf{g})$ & $4-\mathrm{NO}_{2}$ & $\mathrm{Cl}$ & $\mathrm{Cl}$ & PR2 & 99 & $>99(S)$ \\
\hline $17(\mathrm{~h})$ & $4-\mathrm{Cl}$ & $\mathrm{Cl}$ & $\mathrm{Cl}$ & A & 98 & $>99(R)$ \\
\hline $18(\mathrm{~h})$ & $4-\mathrm{Cl}$ & $\mathrm{Cl}$ & $\mathrm{Cl}$ & LB & 91 & $>99(S)$ \\
\hline 19 (i) & $3,4-\mathrm{Cl}_{2}$ & $\mathrm{Cl}$ & $\mathrm{Cl}$ & E. coli/ $\mathrm{A}^{[c]}$ & 99 & $99(R)$ \\
\hline 20 (i) & $3,4-\mathrm{Cl}_{2}$ & $\mathrm{Cl}$ & $\mathrm{Cl}$ & $\operatorname{LB}^{[\mathrm{c}, \mathrm{d}]]}$ & 90 & $98(S)$ \\
\hline 21 (j) & $\mathrm{H}$ & $\mathrm{Br}$ & $\mathrm{Br}$ & E. coli/Ras & 99 & $95(R)$ \\
\hline $22(\mathrm{j})$ & $\mathrm{H}$ & $\mathrm{Br}$ & $\mathrm{Br}$ & $\mathrm{LB}^{[\mathrm{c}, \mathrm{e}]}$ & 99 & $99(S)$ \\
\hline
\end{tabular}

[a] Conversion values calculated by GC. [b] Enantiomeric excess of alcohols calculated using chiral GC or HPLC indicating their absolute configuration in brackets (Note the switch in the CIP priority). [c] 2\% DMSO was added. [d] 48 $\mathrm{h}$ and $4.5 \mathrm{U}$ of enzyme employed. [e] $4.5 \mathrm{U}$ of enzyme employed.

Finally, the bioreduction of a bulkier ketone possessing two bromine atoms at $\alpha$-position instead of chlorines, $\alpha, \alpha$ - dibromoacetophenone (2j), was also analysed finding complete stereoselectivities for anti-Prelog enzymes PR2ADH and LBADH (entry 22 and see also Supporting Information), while RasADH was found as the best Prelog enzyme (entry 21), ADH-A leading to low conversions and high enantiomeric excess, and SyADH produced $(R)-\mathbf{3} \mathbf{j}$ with almost complete conversion but moderate ee (see Supporting Information).

\section{Preparation of racemic $\alpha, \alpha$-dihaloacetophenones}

Due to the high stereoselectivities obtained for ketones $\mathbf{2 a} \mathbf{a} \mathbf{j}$, and in order to broaden the applicability of the already tested alcohol dehydrogenases, the bioreduction of two halogenated racemic ketones was envisaged, so 2-bromo-2-chloro-1-phenylethanone (2k) and 2-chloro-2-fluoro-1-phenylethanone (2l) were prepared following standard procedures. For $\mathbf{2 k}$, $\mathbf{\alpha}$-chloroacetophenone was reacted with NBS in the presence of $p-\mathrm{TsOH}$ in $\mathrm{MeOH}$ at 50 ${ }^{\circ} \mathrm{C}$ for $16 \mathrm{~h}$, yielding the ketone in $85 \%$ isolated yield. On the other hand, fluoro ketone 2l was obtained following the procedure described by Yamazaki et al., starting from ethyl chlorofluoroacetate (56\% yield). ${ }^{[2]}$

\section{Bioreduction of racemic $\alpha, \alpha$-dihaloketones $2 \mathrm{k}-\mathrm{I}$}

Due to the acidity of the a-proton, it was expected that racemisation of the substrates would occur in situ (Scheme 2), making a DKR process feasible obtaining, in the ideal case, one of the four possible diastereoisomer products. ${ }^{[2,30]}$ These enantioenriched alcohols would be of high interest since in a further step they could be selectively modified to obtain more complex and valuable structures due to the different reactivity of both halide atoms.<smiles>[Y][R18]([Y])([H])[H]</smiles>

Scheme 2. Interconversion of both $\mathbf{2 k}$ or $\mathbf{2}$ enantiomers through enolate intermediate.

Therefore, we firstly performed a screening with substrate $\mathbf{2 k}$ (Table 3). In a first set of experiments, it was observed that ADH$\mathrm{A}, \mathrm{RasADH}^{[23 a]}$ and $\mathrm{LBADH}^{[26]}$ were the best biocatalysts in terms of activity and selectivity (entries 1-3). Although still far away from a perfect discrimination, it is remarkable that these enzymes could distinguish between these two halide atoms, since previous results with structurally similar ketones did not show high induction levels. ${ }^{[23 \mathrm{~b}]}$ Since $\mathrm{ADH}-\mathrm{A}$ was the enzyme displaying better diastereoselectivity favouring the formation of syndiastereomer ( $59 \%$, entry 1$)$, we tried to optimise the process by changing several reaction parameters such as $\mathrm{pH}$ or temperature, thus differentially modifying the rate of the enzymatic and the racemisation reactions leading to improved de. While low temperatures showed a negative influence in the activity of the biocatalyst (entry 4), a higher temperature or $\mathrm{pH}$ did not influence the de observed (entries 5-7). Higher pHs afforded the decomposition of both substrate and product forming, among other, benzoic acid. 


\begin{tabular}{|c|c|c|c|c|c|c|}
\hline Entry & $\mathrm{ADH}$ & $\mathrm{T}\left[{ }^{\circ} \mathrm{C}\right]$ & $\mathrm{pH}$ & $\mathbf{3 k}[\%]^{[a]}$ & $e e[\%]^{[b]}$ & $d e[\%]^{[b]}$ \\
\hline 1 & E. coli/ADH-A & 30 & 7.5 & 99 & $>99$ & $59(1 R, 2 R)$ \\
\hline 2 & E. coli/RasADH & 30 & 7.5 & 95 & $>99$ & $1(1 R, 2 R S)$ \\
\hline 3 & LBADH & 30 & 7.5 & 65 & $>99$ & $26(1 S, 2 R)$ \\
\hline 4 & E. coli/ADH-A & 4 & 7.5 & 18 & $>99$ & $58(1 R, 2 R)$ \\
\hline 5 & E. coli/ADH-A & 40 & 7.5 & 86 & $>99$ & $62(1 R, 2 R)$ \\
\hline 6 & E. coli/ADH-A & 30 & 8.5 & 98 & $>99$ & $63(1 R, 2 R)$ \\
\hline 7 & LBADH & 30 & 8.5 & 70 & $>99$ & $33(1 S, 2 R)$ \\
\hline
\end{tabular}

With the aim of gaining a deeper insight in this DKR with $\mathrm{ADH}-\mathrm{A}$, we followed the reaction time course to analyse the rate of the racemisation step together with the de. In case of an inefficient racemisation rate, we would detect a decrease of the diastereomeric excess of the alcohol product within the reaction progress (Figure 1). As can be seen, even at low conversions, the de values remained almost unaltered during the whole process, showing that the racemisation rate was fast enough for the DKR process.

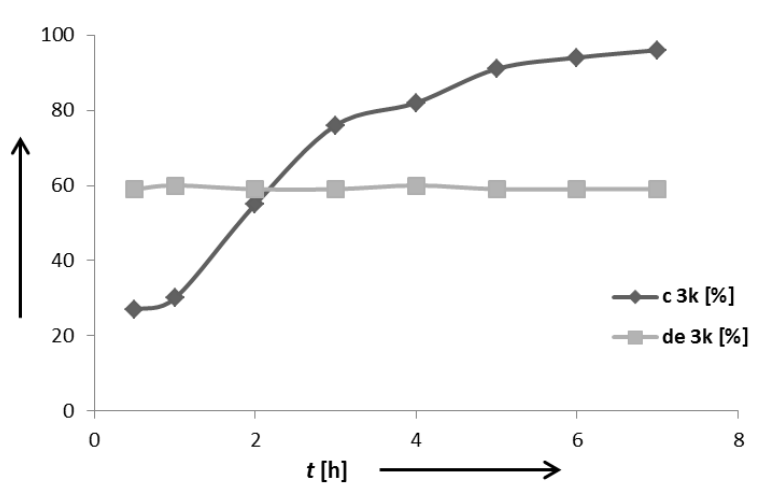

Figure 1. Conversion (black line) and de values (light grey line) in the $E$ coli/ADH-A-catalysed bioreduction of ketone $\mathbf{2 k}$ at $30^{\circ} \mathrm{C}$ and $\mathrm{pH} 7.5$. In all cases ee values were higher than $99 \%$.

Due to the fact that strong basic conditions decomposed both $\mathbf{2 k}$ and $\mathbf{3 k}$, several bases in equimolar amount were added into the reaction medium to study their effect in the DKR process as previously described by us. ${ }^{[30 \mathrm{a}]}$ Thus, DBU (final $\mathrm{pH} 9.0$ ), piperidine (final $\mathrm{pH} 9.0$ ), pyridine (final $\mathrm{pH} 7.5$ ) and triethylamine (final $\mathrm{pH} \mathrm{8.8)} \mathrm{were} \mathrm{employed,} \mathrm{but} \mathrm{no} \mathrm{remarkable} \mathrm{improvement} \mathrm{in}$ the de was detected (see Supporting Information for more details)
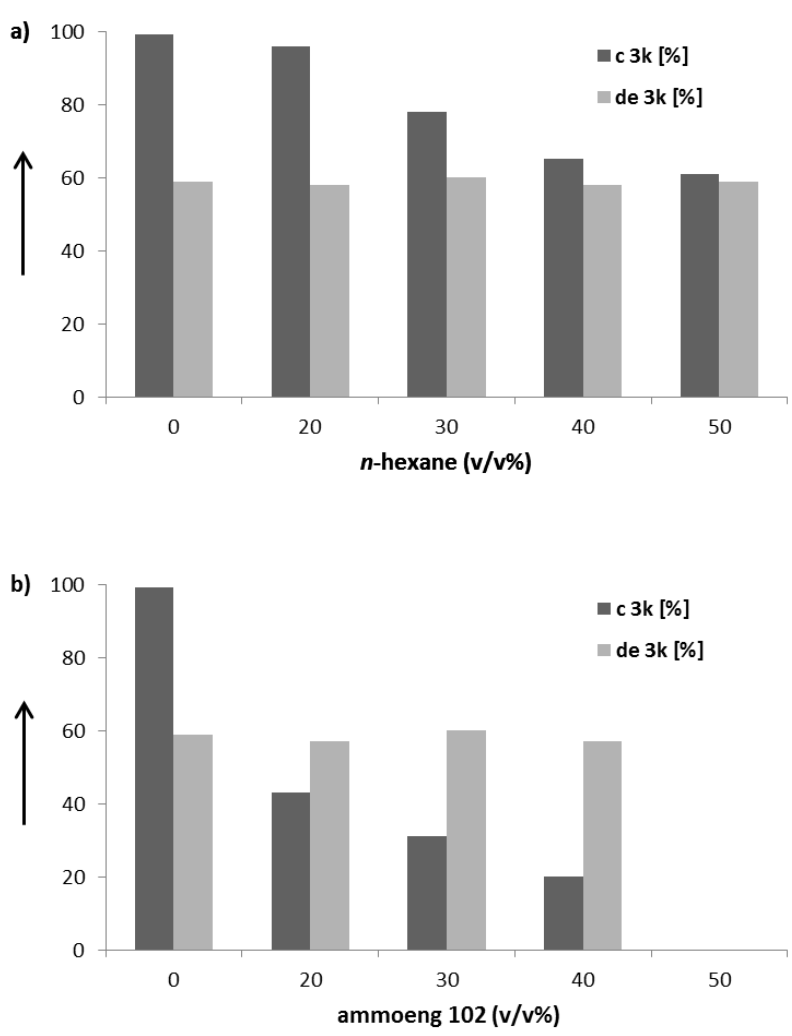

Figure 2. Conversion (black bars) and de values (light grey bars) after $24 \mathrm{~h}$ in the $E$. coli/ADH-A-catalysed bioreduction of ketone $2 \mathbf{k}$ at $30^{\circ} \mathrm{C}$ and $\mathrm{pH} 7.5$ using different proportions of: a) $n$-hexane; and b) Ammoeng 102, as cosolvents. In all cases the ee values were higher than $97 \%$.

Finally, the effect of a non-miscible organic solvent such as $n$ hexane, or a miscible ionic liquid, Ammoeng 102, which already proved to be compatible with $\mathrm{ADH}-\mathrm{A},{ }^{[31]}$ was also measured (Figure 2). The use of an external additive could influence both $\mathrm{ADH}$ selectivity and reaction rates favouring, in the best scenario, the DKR outcome. ${ }^{[30 a]}$ From the results attained, it can be summarised that both biphasic and monophasic media did not have an influence in the enantio- and diastereoselectivity of the process, suggesting that a better biocatalyst to achieve this goal might be constructed by active site-architecture modification rather than medium engineering.

\section{Crystallisation of acylated alcohol 4}

Different attempts were made to obtain suitable crystals for $X$ ray diffraction analysis in order to confirm the relative and absolute configuration of the stereogenic centres of $\mathbf{3 k}$. The most successful approach was achieved, converting the optically active alcohol obtained from the ADH-A-catalysed bioreduction of $\mathbf{2 k}$ into ester 4, after reaction with 4-nitrobenzoyl chloride in the presence of triethylamine in dry dichloromethane, and subsequent crystallisation using a mixture of diethyl ether and $n$ hexane. As can be seen in Figure 3 both stereogenic centres presented the $(R)$-configuration, data for the $\mathrm{C}-\mathrm{OH}$ bond being in agreement with the known stereopreference showed by ADH-A as a Prelog enzyme, and which determined the absolute configuration at position 2 bearing both halogens. ${ }^{[32]}$ 

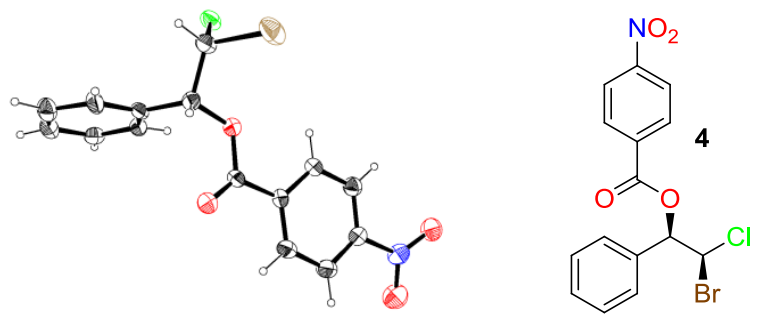

Figure 3. X-Ray structure of ester $(R, R)-4$ synthesised through ADH-A catalysed bioreduction of racemic ketone $\mathbf{2 k}$. Hydrogen atoms appear in white colour.

From the data shown in Table 3 , it is remarkable that ADH-A produced the syn-(1R,2R)-3k diastereoisomer with moderate diastereomeric excess $(63 \%$ de), which stands for a syn configuration, while LBADH slightly preferred the formation of the $(1 S, 2 R)$-3k diastereoisomer (33\% de), which accounts for an ant configuration. On the other hand, it is noteworthy that the reduction of racemic ketone $\mathbf{2 k}$ with sodium borohydride led to the formation of the racemic mixtures at a proportion $3: 1(50 \%$ de) favouring the anti diastereoisomer. The opposite diastereopreference displayed by $\mathrm{ADH}-\mathrm{A}$ compared to $\mathrm{NaBH}_{4}$ or $\mathrm{LBADH}$-catalysed reductions is a very interesting feature, and will be object of further studies.

Next, the DKR of 2-chloro-2-fluoro-1-phenylethanone (2I) was also tried under the best conditions found for ketone $\mathbf{2} \mathbf{k}$, but as shown in Table 4, although excellent conversions and enantioselectivies were observed, low de values were achieved. While Sphingobium yanoikuyae ADH overexpressed in E. coli, afforded the highest value of de $(45 \%)$, although with low ee (59\%, entry 4$)$, the other biocatalysts studied gave access to the enantiopure alcohol $3 \mathbf{l}$ but with vanished diastereoselectivity (entries 1-3). The effect exerted by the fluorine in the diastereomeric excess values was remarkable, probably due to a better recognition of the bulky $\mathrm{Br}$ atom in substrate $\mathbf{2 k}$ with respect to fluorine in ketone $\mathbf{2}$.

\begin{tabular}{|lllll|}
\hline \multicolumn{4}{|c|}{ Table 4. Bioreduction of racemic ketone 2 lat $\mathrm{pH} 7.5$ and $30^{\circ} \mathrm{C}(t=24 \mathrm{~h})}$. \\
Entry & ADH & $\mathbf{3 1}[\%]^{[a]}$ & $e e[\%]^{[b]}$ & $d e[\%]^{[b]}$ \\
\hline 1 & E. coli/ADH-A & 99 & 98 & $5(1 R, 2 R S)$ \\
2 & E. coli/RasADH & 99 & 97 & $<1(1 R, 2 R S)$ \\
3 & LBADH & 99 & $>99$ & $1(1 S, 2 R S)$ \\
4 & E. coli/SyADH & 98 & 59 & $45(1 R, 2 R S)$ \\
\hline
\end{tabular}

[a] Conversion values measured by GC. [b] Enantiomeric and diastereomeric excess measured by chiral HPLC (Note the switch in the CIP priority).

\section{Conclusions}

The successful preparation of $\alpha, \alpha$-dihaloacetophenones as well as an $\mathrm{ADH}$-selection guideline for their stereoselective reduction was provided. Enantioenriched dihalohydrins are precursors in chemical synthesis of a wide number of valuable compounds and their selective synthesis by traditional chemical methods is hampered due to low asymmetric induction or formation of by- products. Thus, different ADHs under mild reaction conditions in aqueous medium were considered as suitable catalysts yielding both enantiomers depending on the choice of the enzyme. A series of dihalohydrins bearing different substitutions in the phenyl ring were obtained with enantiomeric excess over $95 \%$ for both $(R)$ - and $(S)$-enantiomers by the correct selection of the $\mathrm{ADH}$ for the bioreduction process. In addition, eighteen out of twenty of these alcohol enantiomers were achieved with over $90 \%$ conversion, just finding lower conversions for the orthosubstituted substrates.

Moreover, the asymmetric bioreduction of two racemic ketones, namely $\alpha$-bromo- $\alpha$-chloroacetophenone and $\alpha$-chloro- $\alpha$ fluoroacetophenone, was also studied. The use of an organic base or cosolvent, and the modification of the temperature or the $\mathrm{pH}$ did not have a significant effect on the stereoselectivity of the DKR process. While for the first substrate the corresponding enantiopure alcohol was obtained in excellent conversions, albeit with moderate diastereomeric excess, the second one was reduced with low de values. Using X-ray diffraction the absolute configuration of the major diastereoisomer obtained could be assigned. For the second racemic ketone, the ADHs could not differentiate between both halogen atoms. Overall, the bioreduction of $\alpha, \alpha$-dihaloacetophenones has been studied using different $A D H s$, giving access to valuable enantiopure $\beta, \beta$ dihalohydrins possible selecting the proper biocatalyst. This study enables the future application of these enzyme-catalysed processes in the syntheses of more complex chiral compounds.

\section{Experimental Section}

Overexpressed ADHs from Rhodococcus ruber (E. coli/ADH-A), from Ralstonia species (E. coli/RasADH) and Sphingobium yanoikuyae ( $E$. coli/SyADH) were used as lyophilised cells. ${ }^{[23 c, 24,33]}$ Glucose dehydrogenase (GDH 002, $30 \mathrm{U}$ mg-1), ADH-A (20 U/mg), PR2-ADH $(0.13 \mathrm{U} / \mathrm{mg})$, and LBADH from Lactobacillus brevis $(3.7 \mathrm{U} / \mu \mathrm{L})$ were purchased from Codexis. LKADH from Lactobacillus kefir $(0.42 \mathrm{U} / \mathrm{mg})$ was obtained from Fluka. For the bioreduction processes, Tris- $\mathrm{H}_{2} \mathrm{SO}_{4}$ buffer was employed in all cases with $\alpha$-brominated ketones to avoid undesired $\mathrm{S}_{\mathrm{N}} 2$ reactions.

General procedure for the synthesis of prochiral ketones 2a-h. To a solution of the corresponding acetophenone $1 \mathbf{a}-\mathbf{h}(3.7 \mathrm{mmol})$ and $p$-TsOH $(708.8 \mathrm{mg}, 3.7 \mathrm{mmol})$ in acetonitrile $(10 \mathrm{~mL})$, NCS was added $(1 \mathrm{~g}, 7.6 \mathrm{mmol})$. The reaction mixture was heated at $50^{\circ} \mathrm{C}$ and stirred till disappearance of the starting material (16-48 h). After completion, the solvent was evaporated under reduced pressure and the crude was purified using flash chromatography $(50-80 \%$ $\mathrm{CH}_{2} \mathrm{Cl}_{2} /$ hexane) yielding the corresponding prochiral ketones (see Table 1). ${ }^{[34]}$

Synthesis of 2,2-dichloro-1-(3,4-dichlorophenyl)ethanone (2i). To a solution of $\alpha$-chloroacetophenone $1 \mathbf{i}(280 \mathrm{mg}, 1.25 \mathrm{mmol})$ and $p$ $\mathrm{TsOH}(238 \mathrm{mg}, 1.25 \mathrm{mmol})$ in acetonitrile $(4 \mathrm{~mL})$, NCS was added $(184 \mathrm{mg}, 1.37 \mathrm{mmol})$. The reaction mixture was heated at $50{ }^{\circ} \mathrm{C}$ and stirred till disappearance of the starting material (16 h). After completion of the reaction, the solvent was evaporated under reduced pressure and the crude was purified using flash chromatography $\left(20 \% \mathrm{CH}_{2} \mathrm{Cl}_{2} /\right.$ hexane) yielding product $2 \mathbf{i}$ as a white solid $(0.27 \mathrm{~g}$, $83 \%)$.

Synthesis of 2,2-dibromo-1-phenylethanone (2j). To a solution of acetophenone (1a, $250 \mathrm{mg}, 2.08 \mathrm{mmol})$ and $p-\mathrm{TsOH}(3.16 \mathrm{~g}, 16.6$ $\mathrm{mmol})$ in acetonitrile $(20 \mathrm{~mL})$, NBS was added $(1.11 \mathrm{~g}, 6.24 \mathrm{mmol})$. The reaction mixture was heated at $50{ }^{\circ} \mathrm{C}$ and stirred till disappearance of the starting material $(16 \mathrm{~h})$. After completion of the 
reaction, the solvent was evaporated under reduced pressure and the crude was purified using flash chromatography $\left(33 \% \mathrm{CH}_{2} \mathrm{Cl}_{2} /\right.$ hexane) yielding product $\mathbf{2 j}$ as a white solid (467 mg, $81 \%$ ).

Synthesis of racemic 2-bromo-2-chloro-1-phenylethanone (2k). To a solution of $\alpha$-chloroacetophenone $1 \mathbf{k}(500 \mathrm{mg}, 3.2 \mathrm{mmol})$ and $p$ $\mathrm{TsOH}(615 \mathrm{mg}, 3.2 \mathrm{mmol})$ in acetonitrile $(4 \mathrm{~mL})$, NBS was added (863 $\mathrm{mg}, 4.85 \mathrm{mmol})$. The reaction mixture was heated at $50^{\circ} \mathrm{C}$ and stirred till disappearance of the starting material $(16 \mathrm{~h})$. After completion of the reaction, the solvent was evaporated under reduced pressure and the crude was purified using flash chromatography $(20 \%$ $\mathrm{CH}_{2} \mathrm{Cl}_{2} /$ hexane) yielding $\mathbf{2 k}$ as a white solid (0.64 $\left.\mathrm{g}, 85 \%\right)$.

Synthesis of racemic 2-chloro-2-fluoro-1-phenylethanone (2I). To a solution of ethyl chlorofluoroacetate $(4.35 \mathrm{mmol}, 0.5 \mathrm{~mL})$ in dry toluene $(5 \mathrm{~mL})$ at $-78{ }^{\circ} \mathrm{C}$ under nitrogen atmosphere, 1.1 equiv. of phenyl magnesium bromide (1.6 mL of a $3 \mathrm{M}$ solution in $\mathrm{Et}_{2} \mathrm{O}$ ) was added dropwise and the reaction was stirred for one hour. Following that time, the reaction mixture was warmed up to $0{ }^{\circ} \mathrm{C}$ and then left for $10 \mathrm{~min}$ prior to the quenching with ammonium chloride (saturated solution). The crude was extracted with $\mathrm{Et}_{2} \mathrm{O}(3 \times 10 \mathrm{~mL})$, dried over anhydrous $\mathrm{Na}_{2} \mathrm{SO}_{4}$ and was slowly evaporated under reduced pressure in an ice bath to prevent the loss of the volatile product. The crude mixture was purified using flash chromatography $(100 \%$ pentane to $70 \%$ pentane $/ \mathrm{CH}_{2} \mathrm{Cl}_{2}$ ) yielding 2 l as a white crystal solid $(0.42 \mathrm{~g}, 56 \%$ yield $) .{ }^{[29]}$

Bioreduction experiments of ketones 2a-I with $E$. coli/ADH-A. To a $15 \mathrm{mg}$ of overexpressed E. coli/ADH-A (lyophilised cells) in an Eppendorf vial $(1.5 \mathrm{~mL}), 510 \mu \mathrm{L}$ of Tris- $\mathrm{HCl}$ or Tris- $\mathrm{SO}_{4}$ buffer (50 $\mathrm{mM}, \mathrm{pH} 7.5)$ were added, NADH $(60 \mu \mathrm{L}$ of a $10 \mathrm{mM}$ solution, fina concentration: $1 \mathrm{mM}), 2$-propanol $(30 \mu \mathrm{L}, 5 \% \mathrm{v} / \mathrm{v})$ and the corresponding ketone $(\mathbf{2 a}-\mathbf{I}, 25 \mathrm{mM})$. The reaction tubes were shaken horizontally at $30{ }^{\circ} \mathrm{C}$ for $24 \mathrm{~h}$ and $150 \mathrm{rpm}$. After that time, the reaction products were extracted with EtOAc $(2 \times 0.5 \mathrm{~mL})$. The organic layers were separated by centrifugation (1.5 min, $13000 \mathrm{rpm}$ ) and dried over anhydrous $\mathrm{Na}_{2} \mathrm{SO}_{4}$. Conversion and ee values were determined by GC or HPLC analysis.

Scale up of the bioreduction of ketone 2 a with E. coli/ADH-A. In an Erlenmeyer flask (10 mL), E. coli/ADH-A (100 mg) was suspended in $3.6 \mathrm{~mL}$ of Tris- $\mathrm{HCl}$ buffer $(50 \mathrm{mM}, \mathrm{pH} 7.5,1 \mathrm{mM} \mathrm{NADH})$ and preincubated for 30 minutes at $30 \stackrel{\circ}{ } \mathrm{C}$. Then, ketone $\mathbf{2 a}(50 \mathrm{mg}, 0.26$ $\mathrm{mmol})$ and 2-propanol $(0.4 \mathrm{~mL}, 10 \% \mathrm{v} / \mathrm{v})$ were added to the mixture The reaction was shaken at $30^{\circ} \mathrm{C}$ and $250 \mathrm{rpm}$ for $48 \mathrm{~h}$. After incubation, the enzymatic reaction was stopped by extraction with EtOAc $(3 \times 5 \mathrm{~mL})$. The organic layers were combined and dried over $\mathrm{Na}_{2} \mathrm{SO}_{4}$. The solvent was concentrated under vacuum, furnishing the enantiopure alcohol $(R)$-3a (isolated yield: 65\%).

Bioreduction experiments of ketones 2a-I with LBADH. In an Eppendorf vial $(1.5 \mathrm{~mL}), \mathrm{LBADH}(10 \mu \mathrm{L}, 3 \mathrm{U})$ was added to $450 \mu \mathrm{L}$ of Tris- $\mathrm{HCl}$ or Tris- $\mathrm{H}_{2} \mathrm{SO}_{4}$ buffer $(50 \mathrm{mM}, \mathrm{pH} 7.5)$, followed by $\mathrm{NADPH}$ $(60 \mu \mathrm{L}$ of a $10 \mathrm{mM}$ solution, final concentration: $1 \mathrm{mM}), \mathrm{MgCl}_{2}(60 \mu \mathrm{L}$ of a $10 \mathrm{mM}$ solution, final concentration: $1 \mathrm{mM}), 2$-propanol $(30 \mu \mathrm{L}$, $5 \% \mathrm{v} / \mathrm{v})$ and the corresponding ketone $(2 \mathrm{a}-\mathrm{I}, 25 \mathrm{mM})$. The reaction tubes were shaken horizontally at $30 \stackrel{\circ}{ } \mathrm{C}$ for $24 \mathrm{~h}$ and $150 \mathrm{rpm}$. After that time, the reaction products were extracted with EtOAc $(2 \times 0.5$ $\mathrm{mL})$. The organic layers were separated by centrifugation (1.5 $\mathrm{min}$, $13000 \mathrm{rpm}$ ) and dried over anhydrous $\mathrm{Na}_{2} \mathrm{SO}_{4}$. Conversion and ee values were determined by GC or HPLC analysis

Bioreduction experiments of ketones 2a-I with LKADH. $7 \mathrm{mg}$ of $\mathrm{LKADH}(3 \mathrm{U})$ in an Eppendorf vial $(1.5 \mathrm{~mL})$ were added to a $510 \mu \mathrm{L}$ of Tris- $\mathrm{HCl}$ or Tris- $\mathrm{H}_{2} \mathrm{SO}_{4}$ buffer $(50 \mathrm{mM}, \mathrm{pH} 7.5)$, NADPH $(60 \mu \mathrm{L}$ of a 10 $\mathrm{mM}$ solution, final concentration: $1 \mathrm{mM})$, glucose $(30 \mu \mathrm{mol}$ of a $1 \mathrm{M}$ solution, $50 \mathrm{mM})$, glucose dehydrogenase $(10 \mu \mathrm{L}, 3 \mathrm{U})$ and the corresponding ketone (2a-I, $25 \mathrm{mM})$. The reaction tubes were shaken horizontally at $30{ }^{\circ} \mathrm{C}$ for $24 \mathrm{~h}$ and $150 \mathrm{rpm}$. After that time, the reaction products were extracted with EtOAc $(2 \times 0.5 \mathrm{~mL})$. The organic layers were separated by centrifugation (1.5 min, $13000 \mathrm{rpm}$ ) and dried over anhydrous $\mathrm{Na}_{2} \mathrm{SO}_{4}$. Conversion and ee values were determined by GC or HPLC analysis.

Bioreduction experiments of ketones 2a-I with PR2ADH. In an Eppendorf vial $(1.5 \mathrm{~mL}), \mathrm{PR} 2 \mathrm{ADH}(23 \mathrm{mg}, 3 \mathrm{U}), 510 \mu \mathrm{L}$ of Tris- $\mathrm{HCl}$ or Tris- $\mathrm{H}_{2} \mathrm{SO}_{4}$ buffer $(50 \mathrm{mM}, \mathrm{pH} 7.5)$ were added, NADH $(60 \mu \mathrm{L}$ of a 10 mM solution, final concentration: $1 \mathrm{mM}), 2$-propanol $(30 \mu \mathrm{L}, 5 \% \mathrm{v} / \mathrm{v})$ and the corresponding ketone $(2 \mathrm{a}-\mathrm{I}, 25 \mathrm{mM})$. The reaction tubes were shaken horizontally at $30{ }^{\circ} \mathrm{C}$ for $24 \mathrm{~h}$ and $150 \mathrm{rpm}$. After that time, the reaction products were extracted with EtOAc $(2 \times 0.5 \mathrm{~mL})$. The organic layers were separated by centrifugation (1.5 min, $13000 \mathrm{rpm}$ ) and dried over anhydrous $\mathrm{Na}_{2} \mathrm{SO}_{4}$. Conversion and ee values were determined by GC or HPLC analysis.

Bioreduction experiments of ketones 2a-I with $E$. coli/RasADH. To a $15 \mathrm{mg}$ of overexpressed $E$. coli/RasADH (lyophilised cells) in an Eppendorf vial $(1.5 \mathrm{~mL}), 510 \mu \mathrm{L}$ of Tris- $\mathrm{HCl}$ or Tris- $\mathrm{H}_{2} \mathrm{SO}_{4}$ buffer $(50$ $\mathrm{mM}, \mathrm{pH} 7.5)$ were added, NADPH $(60 \mu \mathrm{L}$ of a $10 \mathrm{mM}$ solution, final concentration: $1 \mathrm{mM})$, glucose $(30 \mu \mathrm{mol}$ of a $1 \mathrm{M}$ solution, $50 \mathrm{mM})$, glucose dehydrogenase $(10 \mu \mathrm{L}, 3 \mathrm{U})$ and the corresponding ketone $(2 \mathrm{a}-\mathrm{I}, 25 \mathrm{mM})$. The reaction tubes were shaken horizontally at $30{ }^{\circ} \mathrm{C}$ for $24 \mathrm{~h}$ and $150 \mathrm{rpm}$. After that time, the reaction products were extracted with EtOAc $(2 \times 0.5 \mathrm{~mL})$. The organic layers were separated by centrifugation (1.5 min, $13000 \mathrm{rpm}$ ) and dried over anhydrous $\mathrm{Na}_{2} \mathrm{SO}_{4}$. Conversion and ee values were determined by $\mathrm{GC}$ or HPLC analysis.

Bioreduction experiments of ketones 2a-I with $E$. coli/SyADH. To a $15 \mathrm{mg}$ of overexpressed E. coli/SyADH (lyophilised cells) in an Eppendorf vial $(1.5 \mathrm{~mL}), 510 \mu \mathrm{L}$ of Tris- $\mathrm{HCl}$ or $\mathrm{Tris}-\mathrm{H}_{2} \mathrm{SO}_{4}$ buffer (50 $\mathrm{mM}, \mathrm{pH} 7.5)$ were added, NADPH $(60 \mu \mathrm{L}$ of a $10 \mathrm{mM}$ solution, final concentration: $1 \mathrm{mM})$, 2-propanol $(30 \mu \mathrm{L}, 5 \% \mathrm{v} / \mathrm{v})$ and the corresponding ketone $(\mathbf{2 a}-\mathbf{I}, 25 \mathrm{mM})$. The reaction tubes were shaken horizontally at $30{ }^{\circ} \mathrm{C}$ for $24 \mathrm{~h}$ and $150 \mathrm{rpm}$. After that time, the reaction products were extracted with EtOAc $(2 \times 0.5 \mathrm{~mL})$. The organic layers were separated by centrifugation (1.5 min, $13000 \mathrm{rpm}$ ) and dried over anhydrous $\mathrm{Na}_{2} \mathrm{SO}_{4}$. Conversion and ee values were determined by GC or HPLC analysis.

\section{Acknowledgements}

This project is supported by the BIOTRAINS Marie Curie Initial Training Network, financed by the European Union through the 7th Framework People Programme (grant agreement number 238531). Financial support from the Spanish Ministerio de Ciencia e Innovación (MICINN-12-CTQ2011-24237), Ministerio de Economía y Competitividad (MAT2010-15094, Factoría de Cristalización - Consolider Ingenio 2010), ERDF and the Principado de Asturias (SV-PA-13-ECOEMP-42 and SV-PA-13ECOEMP-43) is also gratefully acknowledged. F.R.B. acknowledges INFIQC-CONICET and Universidad Nacional de Córdoba. I.L. acknowledges MICINN for his research contract under the Ramón y Cajal Program.

Keywords: Alcohol dehydrogenases • Asymmetric synthesis • Bioreduction • Dihalohydrins • Dynamic kinetic resolution

[1] Other authors also describes these compounds as a,a-dihalogenated alcohols or $\alpha, \alpha$-dihalohydrins, but we think that this is an inappropriate way to name this family of compounds.

[2] a) K. Shibatomi, A. Narayama, Y. Soga, T. Muto, S. Iwasa, Org. Lett. 2011, 13, 2944-2947; b) J. M. Concellón, P. L. Bernad, J. A. PérezAndrés, Angew. Chem. 1999, 111, 2528-2530; Angew. Chem. Int. Ed. 1999, 38, 2384-2386.

[3] S. Hahner, M. Fassnacht, Curr. Opin. Investig. Drugs 2005, 6, 386-394. 
[4] H. Kakiya, H. Shinokubo, K. Oshima, Tetrahedron 2001, 57, 10063 10069.

[5] Z. Wang, J. Yin, S. Campagna, J. A. Pesti, J. M. Fortunak, J. Org. Chem. 1999, 64, 6918-6920.

[6] R. N. McDonald, R. C. Cousins, J. Org. Chem. 1980, 45, 2976-2984.

[7] a) C. Lee, J. Kim, H. Lee, S. Lee, Y. Kho, J. Nat. Prod. 2001, 64, 659660 ; b) R. Ulrich, D. Martin, J. Med. Chem. 1992, 35, 2238-2243.

[8] B. Singh, P. Gupta, A. Chaubey, R. Parshad, S. Sharma, S. C. Taneja, Tetrahedron: Asymmetry 2008, 19, 2579-2588.

[9] a) D. Naskar, S. Roy, Tetrahedron 2000, 56, 1369-1377; b) S Chowdhury, S. Roy, Tetrahedron Lett. 1996, 37, 2623-2624.

[10] S. Khamarui, D. Sarkar, P. Pandit, D. K. Maiti, Chem. Commun. 2011, 47, 12667-12669.

[11] B. L. Jensen, J. Jewett-Bronson, S. B. Hadley, L. G. French, Synthesis 1982, 732-735

[12] M. Nakagawa, T. Kawate, T. Kakikawa, H. Yamada, T. Matsui, T. Hino, Tetrahedron 1993, 49, 1739-1748.

[13] P. V. Ramachandran, B. Gong, A. V. Teodorović, J. Fluor. Chem. 2007 128, 844-850.

[14] H. Arasaki, M. Iwata, D. Nishimura, A. Itoh, Y. Masaki, Synlett 2004, 546548.

[15] See, for instance: a) W. Borzęcka, I. Lavandera, V. Gotor, J. Org. Chem. 2013, 78, 7312-7317; b) K. Nakamura, R. Yamanaka, Tetrahedron: Asymmetry 2002, 13, 2529-2533.

[16] There is one report about the bioreduction of an a,a-dibrominated acetophenone derivative using Rhodotorula rubra whole cells with a surfactant obtaining good conversion (82\%) and ee (92\%), see: A Goswami, R. L. Bezbaruah, J. Goswami, N. Borthakur, D. Dey, A. K. Hazarika, Tetrahedron: Asymmetry 2000, 11, 3701-3709.

[17] K. Lundell, T. Raijola, L. T. Kanerva, Enzyme Microb. Technol. 1998, 22 86-93.

[18] T. Matsuda, T. Harada, N. Nakajima, T. Itoh, K. Nakamura, J. Org Chem. 2000, 65, 157-163.

[19] B. Barkakaty, Y. Takaguchi, S. Tsuboi, Tetrahedron 2007, 63, 970-976.

[20] Recent bibliography: a) F. Hollmann, K. Bühler, B. Bühler, in Enzyme Catalysis in Organic Synthesis; K. Drauz, H. Gröger, O. May, Eds.; Wiley-VCH: Weinheim, 2012, pp. 1325-1438; b) F. Hollmann, I. W. C. E Arends, D. Holtmann, Green Chem. 2011, 13, 2285-2313; c) E. GarcíaUrdiales, I. Alfonso, V. Gotor, Chem. Rev. 2011, 111, PR110-PR180; d) M. M. Musa, R. S. Phillips, Catal. Sci. Technol. 2011, 1, 1311-1323.

[21] Selected recent examples: a) G.-C. Xu, H.-L. Yu, X.-Y. Zhang, J.-H. Xu, ACS Catal. 2012, 2, 2566-2571; b) J. Mangas-Sánchez, E. Busto, V. Gotor-Fernández, F. Malpartida, V. Gotor, J. Org. Chem. 2011, 76, 2115 2121; c) F. R. Bisogno, A. Cuetos, A. A. Orden, M. Kurina-Sanz, I. Lavandera, V. Gotor. Adv. Synth. Catal. 2010, 352, 1657-1661; d) J. H. Schrittwieser, I. Lavandera, B. Seisser, B. Mautner, W. Kroutil, Eur. J. Org. Chem. 2009, 2293-2298; e) E. Alanvert, C. Doherty, T. S. Moody, N. Nesbit, A. S. Rowan, S. J. C. Taylor, F. Vaughan, T. Vaughan, J. Wiffen, I. Wilson, Tetrahedron: Asymmetry 2009, 20, 2462-2466; f) F. R. Bisogno, I. Lavandera, W. Kroutil, V. Gotor, J. Org. Chem. 2009, 74, 1730-1732; g) B. Barkakaty, Y. Takaguchi, S. Tsuboi, Tetrahedron 2007 63, $970-976$.
[22] a) E. Hamnevik, C. Blikstad, S. Norrehed, M. Widersten, J. Mol. Catal. B: Enzym. DOI: dx.doi.org/doi:10.1016/j.molcatb.2013.10.023; b) M. Karabec, A. Łyskowski, K. C. Tauber, G. Steinkellner, W. Kroutil, G. Grogan, K. Gruber, Chem. Commun. 2010, 46, 6314-6316.

[23] a) J. Kulig, A. Frese, W. Kroutil, M. Pohl, D. Rother, Biotechnol. Bioeng. 2013, 110, 1838-1848; b) J. Kulig, R. C. Simon, C. A. Rose, S. M. Husain, M. Häckh, S. Lüdeke, K. Zeitler, W. Kroutil, M. Pohl, D. Röther, Catal. Sci. Technol. 2012, 2, 1580-1589; c) I. Lavandera, A. Kern, B. Ferreira-Silva, A. Glieder, S. de Wildeman, W. Kroutil, J. Org. Chem. 2008, 73, 6003-6005.

[24] I. Lavandera, A. Kern, V. Resch, B. Ferreira-Silva, A. Glieder, W. M. F. Fabian, S. de Wildeman, W. Kroutil, Org. Lett. 2008, 10, 2155-2158.

[25] This article specifies the stereopreference of some ADHs, see: V. Prelog, Pure Appl. Chem. 1964, 9, 119-130.

[26] a) S. Leuchs, L. Greiner, Chem. Biochem. Eng. Q. 2011, 25, 267-281; b) M. Wolberg, W. Hummel, C. Wandrey, M. Müller, Angew. Chem. 2000 , 112, 4476-4478; Angew. Chem. Int. Ed. 2000, 39, 4306-4308.

[27] W. Hummel, Appl. Microbiol. Biotechnol. 1990, 34, 15-19.

[28] A. Cuetos, A. Rioz-Martínez, F. R. Bisogno, B. Grischek, I. Lavandera, G. de Gonzalo, W. Kroutil, V. Gotor, Adv. Synth. Catal. 2012, 354, 17431749.

[29] T. Yamazaki, T. Terajima, T. Kawasaki-Takasuka, Tetrahedron 2008, 64, 2419-2424.

[30] For other recent dynamic protocols involving ADHs, see: a) J. MangasSánchez, E. Busto, V. Gotor, V. Gotor-Fernández, Org. Lett. 2013, 15, 3872-3875; b) F. Xu, J. Y. L. Chung, J. C. Moore, Z. Liu, N. Yoshikawa, R. S. Hoerrner, J. Lee, M. Royzen, E. Cleator, A. G. Gibson, R. Dunn, K. M. Maloney, M. Alam, A. Goodyear, J. Lynch, N. Yasuda, P. N. Devine, Org. Lett. 2013, 15, 1342-1345; c) D. Kalaitzakis, I. Smonou, Eur. J. Org. Chem. 2012, 43-46; d) G. A. Applegate, R. W. Cheloha, D. L. Nelson, D. B. Berkowitz, Chem. Commun. 2011, 47, 2420-2422.

[31] a) G. de Gonzalo, I. Lavandera, K. Faber, W. Kroutil, Org. Lett. 2007, 9, 2163-2166; b) G. de Gonzalo, I. Lavandera, K. Durchschein, D. Wurm, K Faber, W. Kroutil, Tetrahedron Asymmetry 2007, 18, 2541-2546.

[32] Crystal data: $\mathrm{C}_{15} \mathrm{H}_{11} \mathrm{BrClNO}_{4}, M=384.61$, monoclinic, $a=12.2449$ (7) $\AA$, $b=10.0624(8) \AA, c=13.1537(7) \AA, \beta=90.428(5)^{\circ}, V=1620.7(2) \AA^{3}, T$ $=293(2) \mathrm{K}$, space group $\mathrm{P} 2_{1}, Z=4$. Crystallographic data (excluding structure factors) for the structure of ester $(R, R)-\mathbf{4}$ have been deposited with the Cambridge Crystallographic Data Centre publication number CCDC 963560. Copies of the data can be obtained free of charge from the Cambridge Crystallographic Data Centre from www.ccdc.cam.ac.uk/cgi-bin/catreq.cgi.

[33] K. Edegger, C. C. Gruber, T. M. PoessI, S. R. Wallner, I. Lavandera, K. Faber, F. Niehaus, J. Eck, R. Oehrlein, A. Hafner, W. Kroutil, Chem. Commun. 2006, 2402-2404.

[34] Adapted from: J. C. Lee, Y. H. Bae, S. K. Chang, Bull. Korean Chem. Soc. 2003, 24, 407-408.

Received: ((will be filled in by the editorial staff))

Published online: ((will be filled in by the editorial staff $))$ 


\section{FULL PAPER}

A series of $\beta, \beta$-dihalohydrins have been obtained through alcohol dehydrogenase-catalysed bioreduction of the synthesised $\alpha, \alpha$ dihalogenated ketones. Moreover, two racemic acetophenone derivatives were also subjected under this protocol to get access to the stereoenriched alcohols via DKR process

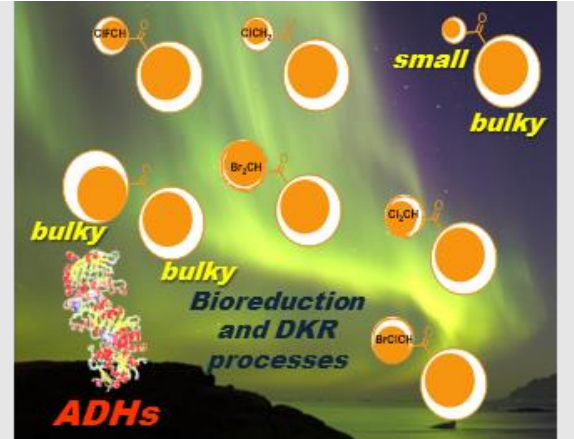

Kinga Kędziora, Fabricio R. Bisogno, Iván Lavandera, Vicente GotorFernández, Jose Montejo-Bernardo, Santiago García-Granda, Wolfgang Kroutil, and Vicente Gotor*

Page No. - Page No.

Expanding the Scope of Alcohol Dehydrogenases towards Bulkier Substrates: Stereo- and

Enantiopreference for $\alpha, \alpha-$ Dihalogenated Ketones 